\title{
现代学徒制背景下职业教育“ 工匠精神”的培育分析
}

\author{
张建军 \\ 新疆铁道职业技术学院哈密校区 \\ DOI:10.32629/jief.v2i6.1137
}

[摘 要] 本文对现代学徒制背景下, 当前我国职业教育 “工匠精神” 培育现状进行了剖析, 从中发现了存在的问题, 并针对培育的问题提出 相应的解决措施，为我国培养高素质技术性人才提供了方法借鉴。

[关键词] 现代学徒制; 职业教育; 工匠精神

中图分类号：G633.98 文献标识码：A

我国进入新时代之后, 高素质技术性人才的需求在不断加大, 国家 也越来越重视职业教育 “工匠精神” 的培养。所以, 必须要探索职业教 育 “工匠精神” 培育的新方法, 为我国的飞速发展奠定人才基础。

\section{1 当前我国职业教育培育现状}

1.1 职业道德水平有待提高

现代学徒制是在我国传统的学徒制基础之上, 与现代职业教育有机 结合, 通过学校教师与企业师傅共同教授专业技能, 从而促进学生发展 的新型教学制度。现代学徒制可以延长学生的职业教育时间, 提高学生 的职业技能水平, 促进学生的全面发展。但是, 调查发现, 在实际教学 过程中, 存在着学生职业道德水平认识不足的问题。在学生参加工作后, 存在着应付工作，敷衍了事的情况。

1.2 职业技术水平较低

培养高素质的技术性人才是职业教育的根本目标。学生的职业技术 水平, 关系到未来的工作质量与工作效率。虽然现代学徒制是学校教师 与企业师傅共同教育学生, 但由于学生的学习能力不足, 以及教师与师 傅间沟通不及时等问题, 在教学培育之后, 仍然存在着学生职业技术水 平较低的情况, 如果不及时纠正, 会影响学生未来的职业发展状况。

1.3 职业心理素质较差

职业心理素质, 要求学生具有较强的自我监督、自我改正的能力, 在从事工作后, 能够克服工作压力, 在面对困难时能及时地调整自己的 心理状态, 以更饱满的热情和工作积极性去应对挑战。调查发现, 当前 我国经过职业教育的学生, 仍然存在着职业心理素质较差的问题。许多 学生由于基础知识有缺陷, 心理承受能力不强, 导致不能积极应对工作 中的困难, 无法承受工作压力和领导批评, 而选择不停地更换工作, 甚 至放弃工作。

\section{2 职业教育 “工匠精神” 的培育措施}

2.1 加强工匠精神宣传教育

从 2016 年开始, “工匠精神” 受到了社会各界的持续关注, 其 “敬 业、精益、专注、创新” 的理念与我国职业教育的教学理念不谋而合。 所以, 提高职业教育学生的道德水平, 应加强工匠精神的教育培训。

首先, 学校与企业要定期组织学生开展工匠精神学习活动, 引导学 生了解工匠精神, 提高学生职业道德水平。例如, 开展 “工匠精神作品 展”、“工匠精神演讲比赛” 等活动, 增加学生的热情, 保证每一个学 生参与到工匠精神的学习中, 使学生能够更充分地了解工匠精神的理念, 提升自身职业理念。其次, 学生也要主动地去学习工匠精神的理念, 改 变传统的思维定式, 形成 “劳动光荣, 技能宝贵” 的价值观, 从而更好 地提高自身的职业道德水平。最后, 国家也要加大工匠精神的宣传力度, 弘扬具有高技能、高品质的职工事迹, 提高全社会对于工人职业的认知
度, 破除传统的观念, 引导大众尊重劳动职工, 提升职工的职业骄傲感。 此外, 企业也要创新管理体制, 加强企业内部的思想建设, 提高企业职 工整体的职业道德水平。还要对工作优秀的职工进行表彰, 增强企业职 工劳动积极性, 使其以更饱满的热情投入到工作之中。

2.2 创新职业教育课程体系

当前我国职业教育学校教授的课程, 主要包括专业理论、专业技能 的学习, 一般不涉及职业理念的教育。并且, 由于个人能力的差异, 学 生对专业理论、专业技能的理解程度不高, 导致自身职业技术水平较低。 所以, 职业教育学校必须要创新职业教育课程体系, 提高学生的职业技 术水平。

首先, 学校要改变传统的教学模式, 在专业理论、专业技能的授课 之外, 加强学生的职业理念教育。其次, 教师要了解学生的需求, 对自 身的教学方法进行完善, 增加学生的学习兴趣, 提高学生的专业理论、 专业技能。最后, 学校教师与企业师傅也要提高自身综合素质, 发挥先 锋模范作用, 引导学生进行学习, 促进学生的全面发展。

2.3 开展工匠精神实践活动

工匠精神需要学生在实际的工作中加深理解, 巩固提高, 进而提高 自身的职业心理素质。

首先, 企业与学校之间要加强沟通交流。企业要为学生提供实习工 作的平台, 让学生在实践中检验自身的能力, 了解自身的不足, 促进能 力的提高。学校也要主动拓宽渠道, 积极寻找更适合学生的工作平台。 其次, 学生要在实践工作中践行工匠精神的理念, 以先进的理念指导日 常工作, 在工作中加深对工匠精神的理解, 形成良性循环, 促进自身能 力的提高。最后, 国家也要继续加强工匠精神的宣传教育, 让工匠精神 贯穿全社会工作的方方面面, 让工匠精神在全社会蔚然成风, 为我国高 质量的健康发展奠定基础, 早日实现 “中国智造” 的目标。

\section{3 结论}

总而言之, 在现代学徒制背景下, 融合 “工匠精神” 理念的职业教 育培育方法, 能够有效地提高学生的职业道德、职业技术水平, 为我国 迈向中国智造目标提供更多高素质的技术型人才。

\section{[参考文献]}

[1]廖潇娜. 基于现代学徒制的工匠精神培育研究 [D].河北科技师范 学院,2019.

[2]于文婧.我国中职教育 “工匠精神” 培养路径研究[D]. 哈尔滨师范 大学,2018.

[3]李雅乐,张建设,杨百春.高职创新创业教育与专业教育融合的瓶颈 及策略研究 [J].高教学刊,2020(27):43-46. 